\title{
New Concepts of Equality of Educational Opportunity
}

\author{
Lin, Yen-Ting \\ Graduate School of Education, Peking University, China
}

Copyright $(2018$ by authors, all rights reserved. Authors agree that this article remains permanently open access under the terms of the Creative Commons Attribution License 4.0 International License

\begin{abstract}
Education is the fundamental of a country and it is one of the important support factors of a nation's growth. As for the educational issues never settled, it also brought up the awareness from a different perspective as for social rank, race, gender, and the area of the students and persuading social justice. The purpose of this study would like to have better strategies of enacting correspondent Chinese future policies on equality of educational opportunity. The time frame of this study traced back pre-industrialization till modern society, it went through the Universal Declaration of Human Rights as it was the foundation of education, reviewed different acts, policies, and majorly cited the Coleman Report as the key reference for corresponding issues of Chinese version No Child Left Behind Act. The Act fell into the similar result of the research done by Ivan Illich the issues are: 1) the amount was insufficient to improve the performance; 2) the money was incompetently spent; 3) educational deprived not only cured by the education. In order to have better value for equality of educational opportunity, there are three new approaches of this study are: 1) focusing on fairness and protection of accessing to school; 2) appropriating education for each student; 3) compensating education for cultural deprivation, culturally disadvantaged learners. Four specific strategies are: 1) enacting correspondent policy for inputting resources, subsidize for educational priority areas (EPA); 2) lower teaching staffs change flow; 3) offering free tutorial classes and mental counseling; 4) empower the family function. The authorities need to focus on "function" and "capability" to integrate five United Nations Educational, Scientific and Cultural Organization (UNESCO) Institute for Education learning support props including "learn to know", "learn to do", "learn to live together", "learn to be", and "learn to change". This study can be followed up the solutions to meet the needs of rural area children and family in order to apply at a designated area as an empirical experiment as a blueprint for national wide policy making references.
\end{abstract}

Keywords Equality of Educational Opportunity, Social Justice, UNESCO, Coleman Report

\section{Introduction}

Education is the fundamental of a country and it is one of the important support factors of a nation's growth. However, the equality of the educational opportunity has always been the issue of persuading social justice. Since early stage of the pre-industrialization different social class group has a different path of education. The issue has become popular after World War II (WWII) and it has been focusing and improving by each country. Equality of educational opportunity seems a good way for improving social justice and commonwealth. In traditional society, social rank and wealth were major "toxics" for labor class. So that labor class children at schools were labeled as the impression of lower class. [1] Due to social discrimination, social structure and lack of social flow exchange they may also reproduce the labor class status which caused the ranking system firmly.

The Universal Declaration of Human Rights released by the United Nations (UN) in 1948 mentioned that "Everyone has the right to education. Education shall be free, at least in the elementary and fundamental stages. Elementary education shall be compulsory." [2] This is for the first time in international law, the term "the rule of law" was used in the preamble of the Declaration. Each government should open vocational or technical schools for different students, in order to receive higher education the school should focus on the capability what learners have and they should be treated equally. [3] On the one hand, the "No Child Left Behind Act" was released in U.S. in 2002 which promoted the equality of educational opportunity and led the concept to the peak. [4] The Act has had advocates, with some education leaders expressing support for the law's stringent accountability mandates, characterizing them as vital levers of change, inclusiveness, and transparency of results. The laws' ultimate effectiveness, some observers have argued, may depend on how closely states and schools stick to its principles of "tough accountability". [5] This act proposed 
standards-based education reform based on the prerequisite that setting high standards and establishing measurable goals could improve individual outcomes in education. The Act required states to develop their state-owned assessments in basic skills. For federal school funding, states need to give these assessments to all students at select grade levels. [6] The No Child Left Behind Act was the source of considerable controversy and debate in the profession of education.

On the other hand, the research done by Johanningmeier \& Richardson in 2008 shown the educational theories and research cases which encourage other countries to reflect their educational policies. [7] Researchers' responses have had long-term consequences as seen in the reaction to The Coleman Report, the ongoing discussion about the merits of No Child Left Behind. The introduction gives the background information of persuading equality of educational opportunity is important worldwide no matter modern or developing countries. Moreover, as China now is focusing on fundamental education since 2001 the government has brought the new policy for education which has insights from the Coleman Report and adapted from No Child Left Behind Act. In addition, Jacques Lucien Jean Delors, the former EU (European Union) chair, UNESCO chair, and the economist, as well as a great politician in France, has stated in 2011 that education is the best tool for persuading freedom, peace, and social justice. Education assists each one to develop his or her gifts, talents and potentials. [8] Equality of educational opportunity is the concept based on fairness, justice and social justice. The following part cited The Coleman Report and integrated with the historical insights by introducing the time frame from pre-industrial stage to modern society in the West and the East.

\section{Historical Insights and Review}

In The Coleman Report, the data were collected from a sample of schools national wide in the U.S. The Report data consists of age, gender, race and ethnic identity, social background, attitudes toward learning, education and other aspects. James Coleman believed that in the pre-industrialization stage children had limited vision with less social exchange flow in training or education institutes. They have got very little information base on where they came from, the family has the full power and responsibility to decide what and when the child should learn. Majorly, the child takes over the family business without a doubt. Therefore, there is an assumption in The Coleman Report as following: "Within social exchange flow and compare, education would be maximizing its value. [9]" Different classes should be intergraded and developed by blending social background, race, and remove the barriers for the better value it would be created.
In Coleman's point of view, he believed that the pre-industrialization stage couldn't reach the concept of equality of educational opportunity; during the industrialization which he aimed is his report of the U.S. educational social movements, he discovered that the key elements are: 1) offering certain level of free education; 2) offering all children general programs; 3) supporting different social background children to go to the same school; 4) offering certain opportunity for children. Those elements are the foundation of educational equality and the report brought up many countries reflected their principles of compulsory education. However, there are many drawbacks at this time: 1) the child was under parents' control of learning programs in either educational or vocational; 2) the education was free and the government would like to make sure everyone on the same path so that the education programs are general; 3 ) in the past different races of students were separated although the government insisted "isolation but equal"; 4) there were around $70 \%$ of students are not able to access to the college but the curriculum was designed for those who attending to the college.

Although Coleman's report has brought up the awareness of the importance of educational equality, it also raises discussions and arguments. The Report widely cited in the field of sociology of education it helped reformed educational theory, reshape national education policies, and it raised public and scholarly opinion regarding the role of schooling in turns of educational equality. The report consists of three parts: 1) equality of the inputting of education: at the starting point of education, every student should have the same chance; 2) equality of educational process: isolation is not equal and its unfair, both learning environment and, resources should be equal; 3) equality of the outputting of education: learning results should be the same, students from different backgrounds should obtain the same result on achievements or same chance for further studies. All these three parts and five points are able to generate into two categories: input and output of education. Coleman discovered that the standard of "isolation but equal" actually disobeyed the first assumption that child goes to the same type of the school. This standard was used in southern states from 1896 till the 1950s and at the end the U.S. High Court has declared that the theory of "isolation but equal" is unfair.

In contrast, the social justice awareness on education rights in China was first raised in 2001. It adopted the acts and policies from other countries and reformed as to fit in Chinese culture. "The $10^{\text {th }}$ Five Year Plan of National Educational Career" first aimed equality of educational opportunity and educational reform and development as the fundamental principles. As Chinese version of 'No Child Left Behind Act' this Plan is mainly focus on 1) waiving discriminations on different social class children accessing to schools; 2) seeking for fair chance of 
admitting into universities for each region students; 3) different region and different income family should obtain same chance of receiving education in order to offer lifelong education and social justice for each citizen; 4) based on humanity and science innovation for a greater China vision which has the correspondent educational value as the Coleman Report. However, the Plan was well organized by its purposes but not practical in fulfilling social justice base on the various cultural differences in different provinces it was fell into the similar result of the research done by Ivan Illich. The federal aid program- Title One invested over three billion dollars for about six million disadvantaged children. The input was a total failure in three ways: 1) the amount was insufficient to improve the performance for six million students by its amount and it was not specifically funded to those in need; 2) the money was incompetently spent: different curricula, concentration of the funds on the poor child; 3) educational deprived not only cured by the education within the school. [10] In order to have a better value of educational equality the following part is the new concepts and solutions for specific invest in education.

\section{New Concepts and Solutions}

There are many aspects of equality of educational opportunity. Among them, the most argumentative issue is the output of education, for which both national and international scholars hold different positions. Although the authority has controlled the equality of the input and process of education, they still cannot guarantee the output of education. In general, the output of education indicated that the achievement is the same; somehow the achievement cannot represent learners' learning performances, results, or their potential. [11] In modern society, the equality of capability is more meaningful than equality of outputting education. Coleman also pointed out that if there's no social mobility then there will be no inequality. [12] However, in this democratic and open society, symbolic value, practical value, and obtainable skills are common social mobility. According to the Plan that Chinese Government brought up in 2001, the key solutions are major in finance, policy reform, and lifelong education. The ideas are good but not specific enough for the authority to make detail or completed vision project to the correspondent group of people need to be assisted.

In order to have better standard of equality of educational opportunity, there are three new approaches: 1) focusing on fairness and protection of accessing to school: eliminating the inequality or gap among various backgrounds of where students came from (e.g. social class, gender, race, religion......etc.) and leading to the goal of "No Child Left Behind"; 2) appropriating education for each student: school facilities, courses, curriculums, teachers designed for general students are the bottom line of the standard, here focusing on gifted or special need learners leads to the goal of "Capability-Driven Education"; 3) compensating education for cultural deprivation, culturally disadvantaged learners in order to have positive discrimination input of education . [13]

To obtain the principles of the modern educators, the authorities need to focus on two aspects "function" and "capability". The Nobel Prize awardee Amaryta Sen mentioned "Cultivating personal capability is the foundation of persuading freedom and happiness. It's the key for social mobility. [14]" The definition of Social mobility is as the movement of individuals, families, households, or other categories of people within or between different classes in an open system of the society. It matches the assumption as Coleman mentioned in the Report which indicates that the social development is on the right track.

In terms of carrying social mobility, both function and capability play important roles. Function indicated that the subject receiving education, embrace dignity, attending social events...etc. Function and social life are connected to our lives. Capability could reach different combinations which realize your personal valuable and meaningful life. The freedom of the agency is the most important item by following that the achievement is judging by personal value is not judging by an external standard.

Moreover, the equality of capability as the equality of output could have complied with individual differences. In addition, the UNESCO Institute for Education learning support props [15] are "learn to know"- to acquire a moral taste for learning in your life and understanding the world; "learn to do"- be able to deal with different situations, and be a doer and a thinker.; "learn to live together"-try develop an understanding for other people and their history, traditions and believes, in order to participate and co-operate with others; "learn to be"- to develop one's personal value and be able to act with greater autonomy, judgment and personal responsibility; and "learn to change"- as to develop respect for the environment and the society. These are the five basics of solving equality of educational opportunity by integrating props, hands-on activities or build up their true abilities [16] into positive discriminations education. This series of learning props meet the national curriculum reform and is able to integrate into different subjects.

However, there are many problems related to education of remote areas. Take China as an example: the coastal area and inner land area, East and West part of the land, and modern city and rural area have got different difficulties. 1) Although there is a $4 \%$ GDP governmental founding invest annually it still far away from solving the imbalance situation of inequality of education; 2) The development of fundamental education was deprived from higher education, it means the input was imbalance; 3) Preschool 
education is still no fairly implement in each county; 4) Disadvantaged and lower social class family were treated discriminated. The authority needs to deal with economics, teacher training, and family education. Here are some specific strategies for the new concepts: 1) enacting correspondent policy for inputting resources, subsidize for educational priority areas (EPA), special need, aboriginal (ethnical), grand-parenting, foreign spouse family, single parent family...etc. input the money to those people in need especially the target school districts with high concentrations. Give the target schools provisions intended to give greater flexibility in how they spent a portion of their allotments, evaluate the progress annually for exam the next year founding and check benchmark performances instead of inputting investment as in region should be invested as cases or certain groups; 2) lower teaching staffs change flow by topping up the allowance (housing, transportation, benefit...etc.), offering various teacher training program and providing new teaching staffs mentor instruction system, the training program could cover teach new teachers how to teach and be a professional teacher (pre-service training internship as a volunteer at schools, learning teaching knowledge, courses; in-service training of updated technology practice, new teaching methods or skills). The mentor system offers the help of the senior teacher who had got the better reputation on the teaching field could be new teacher's role model and gives new teacher comments and suggestions; 3 ) offering free tutorial classes and mental counseling activity for students, universities could send students as interns to help those culturally deprived learners for the on line or off line tutorial classes, as well as the psychologist counseling programs, those disadvantaged students need both academic and mental support; 4) supporting lower social class family and enhancing family education, not only financial subsidy but also the teacher-parent communication and education by offering workshop and seminar of how guardian educate the child and communicate in both way between family and school.

\section{Discussion and Conclusions}

In this study, the researcher reviewed The Coleman Report and summarized historical insights of the past researches and the No Child Left Behind policy between the U.S. and China also give out the new concepts and solutions for authorities to improve equality of educational opportunity. The new concepts integrated the modern key factors of equality "function", "capability", and UNESCO learning support props for carrying the lifelong skills. Reviewing the Plan from the Chinese version of No Child Left Behind the researcher gave out four specific strategies which reflected from the drawbacks of the Plan, discovered from the teaching site, and review from experienced teaching faculties at schools. For further studies, follow up the solutions to meet the needs of rural area children and family in order to apply at a designated area as an empirical experiment as a blueprint for national wide policy making references. Currently, the awareness of equality of educational opportunity has been rising up in modern education reform. It plays an important role in civilization, economic development and reaches the goal of homonymous society. It is the duty of the government for persuading justice and a step stone of social justice.

\section{Acknowledgments}

The author would like to express appreciation for the financial support of the research grant of Peking University, P. R. China.

\section{REFERENCES}

[1] Universal Declaration of Human Rights, United Nations, 1948.

[2] Tawney, R. H. Equality. London: George Allen \& Unwin; 1964. (First published in 1931, 4th edition.)

[3] Dan, Z. W., Kuo, R. F.. The Theory and Practice of Children Rights for Education. Education Research. 1987;68:56-69.

[4] Nash, R. Equality of Educational Opportunity: In Defense of a Traditional Concept. Educational Philosophy and Theory. 2004;36(4):361-377.

[5] West, Martin R., Peterson, Paul E. The Politics and Practice of Accountability from No Child Left Behind. In: West and Peterson (eds.) The Politics and Practice of Accountability, Washington, DC: The Brookings Institution; 2003. p. 147-158.

[6] New York State Education Agency. Federal Legislation and Education in New York State 2005: No Child Left Behind Act. New York State Education Agency, 2005.

[7] Johanningmeier, E. V., Richardson, T. R. Educational Research, the National Agenda, and Educational Reform: A History. North Carolina: Information Age Publishing; 2008.

[8] Hsu, C. F. Education- The Last Ideal State. Common Wealth Magazine. 1996;11:224-227.

[9] Coleman, J. S. The Concept of Equality of Educational Opportunity. Harvard Educational Review. 1968;38(1):1-22.

[10] Ivan Illich. Deschooling Society. London: Calder \& Boyars Publishers; 1971.

[11] Wang, J. T. Discussion on Equality of Educational Opportunity and Fairness- Base on Concept Analyze, Educational Policy Forum. 1998;1(2), 118-132. 
[12] Coleman, J. S. The Concept of Equality of Educational Opportunity. Harvard Educational Review. 1968;38(1):1-22.

[13] Yang, Y. Equality of Educational Opportunity- Insights from Educational Sociology. Taipei: National Taiwan Normal University Publisher; 1994.

[14] Lee, R. K., Dang, K. Y. 1998 Nobel Prize Economics
Awardee- Amaryta Sen's Academic Contribution. Economics Information 1998;11:50-58.

[15] UNESCO Institute for Education. Nurturing the Treasure. Vision and Strategy 2002-2007. UNESCO, 2003.

[16] Sung, P. F. Cultivating true abilities: Rethinking integration and subject matter knowledge. Journal of Educational Research. 2003;115:12-136. 